\title{
Ectopic Expression of the Catalytic Subunit of Telomerase Protects against Brain Injury Resulting from Ischemia and NMDA-Induced Neurotoxicity
}

\author{
Hyo Jung Kang, ${ }^{1 *}$ Yoon Sik Choi, ${ }^{2 *}$ Seung-Beom Hong, ${ }^{2 *}$ Kee-Won Kim, ${ }^{3}$ Ran-Sook Woo, ${ }^{3}$ Seok Joon Won, ${ }^{1}$ \\ Eun Ju Kim, ${ }^{2}$ Hee Kyung Jeon, ${ }^{2}$ So-Young Jo, ${ }^{2}$ Tae Kook Kim, ${ }^{4}$ Robert Bachoo, ${ }^{5}$ Ian J. Reynolds, ${ }^{6}$ Byoung Joo Gwag, ${ }^{1}$ and \\ Han-Woong Lee ${ }^{2}$ \\ ${ }^{1}$ Departments of Neuroscience and Pharmacology, Ajou University School of Medicine, Suwon 442-749, Korea, ${ }^{2}$ Department of Molecular Cell Biology, \\ Samsung Biomedical Research Center, Sungkyunkwan University School of Medicine, Suwon 440-746, Korea, ${ }^{3}$ Department of Pharmacology and Institute \\ for Medical Sciences, Chonbuk University Medical School, San 2-20 Keumam-dong, Chonju 561-180, Korea, ${ }^{4}$ Department of Biological Sciences, Korea \\ Advanced Institute of Science and Technology, Taejon 305-701, Korea, ${ }^{5}$ Department of Adult Oncology, Dana Farber Cancer Institute, Harvard Medical \\ School, Boston, Massachusetts 02115, and ' Department of Pharmacology, University of Pittsburgh, School of Medicine, Pittsburgh, Pennsylvania 15261
}

The catalytic subunit of telomerase reverse transcriptase (TERT) protects dividing cells from replicative senescence in vitro. Here, we show that expression of TERT mRNA is induced in the ipsilateral cortical neurons after occlusion of the middle cerebral artery in adult mice. Transgenic mice that overexpress TERT showed significant resistance to ischemic brain injury. Among excitotoxicity, oxidative stress, and apoptosis comprising of routes of ischemic neuronal death, NMDA receptor-mediated excitotoxicity was reduced in forebrain cell cultures overexpressing TERT. NMDA-induced accumulation of cytosolic free $\mathrm{Ca}^{2+}\left(\left[\mathrm{Ca}^{2+}\right]_{c}\right)$ was reduced in forebrain neurons from TERT transgenic mice, which was attributable to the rapid flow of $\left[\mathrm{Ca}^{2+}\right]_{c}$ into the mitochondria from the cytosol without change in $\mathrm{Ca}^{2+}$ influx and efflux through the plasma membrane. The present study provides evidence that TERT is inducible in postmitotic neurons after ischemic brain injury and prevents NMDA neurotoxicity through shift of the cytosolic free $\mathrm{Ca}^{2+}$ into the mitochondria, and thus plays a protective role in ameliorating ischemic neuronal cell death.

Key words: catalytic subunit of telomerase; ischemia; excitotoxicity; NMDA; calcium; mitochondria

\section{Introduction}

Telomere terminal transferase, or telomerase, a ribonucleoprotein complex that maintains telomere length and architecture of the linear chromosomes in eukaryotic cells, consists of several proteins including a catalytic subunit $(130 \mathrm{kDa})$ called telomerase reverse transcriptase (TERT) (Nugent and Lundblad, 1998). Telomerase acts as a reverse transcriptase (RT) that contains an intrinsic RNA component (TERC). A central function of telomerase is to prevent the progressive shortening of lagging strands resulting from incomplete replication of the $3^{\prime}$ telomeric end during cell division (Harley et al., 1990). This implicates that

\footnotetext{
Received Sept. 4, 2003; revised 0ct. 22, 2003; accepted 0ct. 22, 2003.

This work was supported by 21C Frontier Functional Human Genome Project Grant FG01-0304-002-1-0-0 from Korean Ministry of Science and Technology (MOST), National Research Laboratory through MOST, Korea Science and Engineering Foundation (KOSEF) through Science Research Center-Molecular Therapy Research Center, Samsung Biomedical Research Institute (H.W.L.), and KOSEF through Brain Disease Research (enter at Ajou University (B.J.G.) We thank the staff of the Laboratory Animal Research Center of Sungkyunkwan University School of Medicine for technical assistance.

*H.J.K., Y.S.C., and S.-B.H. contributed equally to this work.

Correspondence should be addressed to Han-Woong Lee, Department of Molecular Cell Biology, Samsung Biomedical Research Institute, Sungkyunkwan University School of Medicine, Suwon 440-746, Korea, E-mail: hwl@skku.ac.kr, or Byoung Joo Gwag, Departments of Neuroscience and Pharmacology, Ajou University School of Medicine, Suwon 442-749, Korea, E-mail: bjgwag@madang.ajou.ac.kr.

DOI:10.1523/JNEUROSCI.4082-03.2004

Copyright $\odot 2004$ Society for Neuroscience $\quad 0270-6474 / 04 / 241280-08 \$ 15.00 / 0$
}

telomerase plays pivotal roles in the maintenance of chromosomal integrity and ultimate cell viability. Most of the tissues during embryonic development express telomerase activities (Wright et al., 1996; Greenberg et al., 1998; Martin-Rivera et al., 1998), but the activity greatly decreases thereafter and is low or undetectable in most human somatic tissues (Kim et al., 1994; Burger et al., 1997; Shay and Bacchetti, 1997). Among all components of the telomerase complex, expression level of TERT is most closely matched to the level of telomerase enzyme activity (Meyerson et al., 1997; Nakamura et al., 1997; Greenberg et al., 1998). TERT expression decreases with differentiation process at developmental and postnatal stages, and the concomitant lack of telomerase activity causes telomere shortening in human somatic tissues during adult life. This progressive telomere shortening contributes to replicative senescence (Harley et al., 1990; Kim et al., 1994; Bodnar et al., 1998).

Evidence has accumulated showing additional functions of telomerase in dividing and somatic cells that prevent cell death. Transgenic mice and cardiac myocytes expressing TERT reveal a reduced area of myocardial infarction after coronary artery ligation and reduced sensitivity to apoptosis, respectively (Oh et al., 2001). Pheochromocytoma cells that overexpress TERT are protected from trophic factor withdrawal-induced and amyloid peptide-induced apoptosis (Fu et al., 2000; Zhu et al., 2000). 
Suppression of TERT levels in primary neuronal cell cultures increases the vulnerability to excitotoxins and amyloid peptides (Fu et al., 2000; Zhu et al., 2000). Thus, altered expression of TERT appears to influence survival of neurons and non-neuronal cells.

Although TERT expression and telomerase activity are undetectable or low in most postmitotic tissues of the adult (Kim et al., 1994; Shay and Bacchetti, 1997; Greenberg et al., 1998; MartinRivera et al., 1998), recent data suggest that TERT is not only reactivated in transformed cells but may be induced in normal vascular smooth muscle cells after a metabolic stress such as hypoxia (Seimiya et al., 1999; Minamino et al., 2001). We observed that TERT is also induced in ischemic cortical areas after occlusion of the middle cerebral artery (MCAO). In light of induction and protective role of TERT against various toxic insults in mature tissues, we reasoned that beneficial effects of TERT would be extended to mature neurons in adult brain. To examine this hypothesis, we produced transgenic mice overexpressing TERT and studied protective effects of TERT against the hypoxicischemic injury. In addition, mechanisms underlying the putative roles of TERT against neuronal injury were studied using mixed cultures of neurons and glia, in which the major causes of neuronal death such as excitotoxicity, oxidative stress, and apoptosis have been well established.

\section{Materials and Methods}

In situ hybridization. Brains were removed after mice were killed, immediately frozen on dry ice, and stored at $-70^{\circ} \mathrm{C}$. Brains were sectioned at $16 \mu \mathrm{m}$ thickness and mounted onto gelatin-coated slides. To prepare complimentary RNA probe (cRNA) for in situ hybridization histochemistry, the fragments of mouse TERT (mTERT) cDNA (522 bp) and NF-L (neurofilament light chain) cDNA (180 bp) were amplified by PCR and subcloned in pGEM-T Easy vector (Promega, Madison, WI). After linearization of the plasmids, digoxigenin- or fluorescein-labeled sense or antisense RNA probes were synthesized with a SP6/T7 RNA labeling kit (Roche Products, Mannheim, Germany) according to the instructions of the manufacturer. After fixation and acetylation, forebrain sections were hybridized with labeled RNA probes at $42^{\circ} \mathrm{C}$ for $16 \mathrm{hr}$ in the hybridization solution containing: $300 \mathrm{~mm}$ sodium chloride, $2 \times \mathrm{SSC}, 1 \mathrm{mg} / \mathrm{ml}$ of tRNA, $1 \mathrm{mg} / \mathrm{ml}$ of salmon sperm DNA, $2 \%$ dextran sulfate, $50 \%$ formamide, and riboprobes $(50-100 \mathrm{ng} / \mathrm{ml})$. Sections were then washed in $0.1 \times$ SSC at $60^{\circ} \mathrm{C}$ and incubated for $1 \mathrm{hr}$ at room temperature with anti-digoxigenin Fab fragments coupled to rhodamine (Roche Products), diluted $1: 500$ in 10\% fetal calf serum in PBS plus $0.1 \%$ Tween 20 (PBST). After washes in PBST, fluorescence signal of TERT mRNA was examined under confocal microscope.

Generation of mouse telomerase transgenic mice. For construction of transgenic mice, the full-length mTERT cDNA encoding 1,132 amino acids were subcloned into EcoRI site of pCAGGS expression vector (Niwa et al., 1991). Expression of the transgene was driven by a human cytomegalovirus immediate-early enhancer linked to the chicken $\beta$-actin promoter. The inserted fragment was cut from the vector with SalI and HindIII and purified by agarose gel electrophoresis. The transgenic mice were generated by microinjection of the purified DNA into pronuclei of fertilized eggs of FVB/N mice. Transgenic animals were identified by PCR amplification and Southern blot analysis of tail DNA. Three founders were established and characterized further. Mice were housed in colony cages and maintained on a $12 \mathrm{hr}$ light/dark cycle. Most experiments were performed with animals 5-10 weeks of age. All experiments were performed in the Association for Assessment and Accreditation of Laboratory Animal Care certified facility in compliance with approved animal policies by Sungkyunkwan University School of Medicine.

$R T-P C R$. Total RNA from various tissues of the adult transgenic mice was prepared with Trizol reagent (Invitrogen, San Diego, CA). To remove genomic DNA contamination, isolated RNAs were incubated with DNaseI for $1 \mathrm{hr}$ at $37^{\circ} \mathrm{C}$. Reverse transcription reaction was performed using $1 \mu \mathrm{g}$ of total RNA with Superscript II reverse transcriptase (Invitrogen) at $42^{\circ} \mathrm{C}$ for $60 \mathrm{~min}$ after hybridization with $100 \mathrm{ng}$ of $6 \mathrm{nt}$ random hexamer. As a control, reactions were also performed in the absence of reverse transcriptase. Amplification was performed using Taq polymerase for 30 cycles, each cycle consisting of $94^{\circ} \mathrm{C}$ for $30 \mathrm{sec}$ and $60^{\circ} \mathrm{C}$ for 30 sec. Primer pairs 5'-tgggaagaccatgcggaa $3^{\prime}$ (sense primer), 5'tgatgcagactgtctggaggc- $3^{\prime}$ (antisense primer) were used to amplify TERT cDNA. To normalize the amounts of input RNA, amplification of glyceraldehyde-3-phosphate dehydrogenase (GAPDH) RNA was used as a control.

Telomerase activity assay. Telomerase activity was measured by using the TRAP (Telomeric Repeat Amplification Protocol)-eze telomerase detection kit (Intergen, Purchase, NY) according to the instructions of the manufacturer. In brief, thin slices of frozen brain were prepared and then immediately transferred to a sterile tube containing $1 \times 3$-[(3cholamidopropyl)dimethylammonio]-1-propanesulfonate lysis buffer. The sample was homogenized with a motorized pestle and kept for 30 min on ice. After centrifugation for $20 \mathrm{~min}$ at $12,000 \times g$ at $4^{\circ} \mathrm{C}$, the resulting supernatant was subjected to PCR amplification. For the detection of telomerase-mediated laddering, a substrate oligonucleotide (TS) (provided with the kit) was end labeled with $\gamma^{-}{ }^{32} \mathrm{P}$-ATP. PCR products were resolved on a $12.5 \%$ nondenaturing polyacrylamide gel and exposed to a PhosphoImager screen (Molecular Dynamics, Sunnyvale, CA).

Ischemia induction and measurement of injury volume. Adult male mice were anesthetized intraperitoneally with chloral hydrate $(400 \mathrm{mg} / \mathrm{kg})$. For permanent ischemia induction, the right middle cerebral artery was occluded permanently by electrocoagulation as described by Shigeno et al. (1985). Twenty-four hours after permanent occlusion, the mice were anesthetized with chloral hydrate $(400 \mathrm{mg} / \mathrm{kg})$ and decapitated. Brains were removed immediately and placed in ice-cold saline for $10 \mathrm{~min}$ and sectioned coronally into five slices ( $2 \mathrm{~mm}$ thick) in a rodent brain matrix (Harvard Apparatus, Holliston, MA). Brain slices were placed in $2 \%$ 2,3,5-triphenyltetrazolium chloride monohydrate (TTC) (Sigma, St. Louis, MO) at room temperature for $30 \mathrm{~min}$ (Bederson et al., 1986) followed by $10 \%$ formalin overnight. Brain slices were directly scanned on an image scanner. The area of ischemic injury was measured (NIH Image software) on the posterior surface of each section. The injury volume was calculated by numeric integration of the sequential areas.

Primary forebrain cell culture. Embryonic brains were prepared from fetal FVB/N mice at $15.5 \mathrm{~d}$ gestation and mechanically triturated as described previously (Noh and Gwag, 1997). Dissociated cells were plated on 24 well plates (both hemispheres per plate, $\sim 10^{5}$ cells/well) in a plating medium consisting of Eagle's minimal essential media (Invitrogen) supplemented with $5 \%$ horse serum, $5 \%$ fetal bovine serum, $2 \mathrm{~mm}$ glutamine, and $21 \mathrm{~mm}$ glucose. Proliferation of non-neuronal cells was halted by adding cytosine arabinoside (final concentration, $10 \mu \mathrm{M}$ ) at day 6 in vitro (DIV 6) when astrocytes became confluent. Cultures were then fed twice a week with plating medium lacking fetal serum. Cultures were maintained at $37^{\circ} \mathrm{C}$ in a humidified $5 \% \mathrm{CO}_{2}$ atmosphere.

Postnatal day 19 cell culture and differentiation. Postnatal day (P) 19 embryonic carcinoma stem cells, obtained from American Type Culture Collection (CRL-1825), were cultured and differentiated to neuron-like cells as described previously (Boutou et al., 2000). For transfection to P19 cells, the $3^{\prime}$-end of mTERT was tagged by the PCR-based addition of oligonucleotides for hemagglutinin and then subcloned into pCDNA3 expression vector. The expression vector $(3 \mu \mathrm{g})$ was transfected to P19 cells $\left(3 \times 10^{5}\right)$ plated on $60 \mathrm{~mm}$ dishes. Twenty-four hr after transfection, cells were grown in the presence of $1 \mathrm{mg} / \mathrm{ml}$ of G418 (Roche Molecular Biochemicals). After $10 \mathrm{~d}$ of selection, eight clones of resistant cells were collected. To differentiate P19 cells, they were plated at a density of $1 \times 10^{5}$ cells $/ \mathrm{ml}$ in $\alpha$-MEM supplemented with 5\% FBS and 500 nM retinoic acid (RA) in $100 \mathrm{~mm}$ bacteriological grade Petri dishes. RA was removed after $2 \mathrm{~d}$, and cultures were fed with fresh RA containing media. After $2 \mathrm{~d}$, the aggregates were mechanically dissociated and transferred onto confluent glia bed with a density of $3.6 \times 10^{6}$ cells per 24 well plate in $\alpha$-MEM containing $10 \%$ FBS. On the second day after plating, culture media were switched to Eagle's MEM supplemented with $20 \mathrm{~mm}$ glucose, 5\% FBS, 5\% horse serum, and $20 \mu \mathrm{M}$ Ara-C. The Ara-C was 
removed $2 \mathrm{~d}$ later and then fed every $2 \mathrm{~d}$. Excitotoxicity experiments were performed between days 10 and 12.

Analysis of neuronal death. Overall cell injury was assessed microscopically under phasecontrast optics and by measuring the amount of lactate dehydrogenase $(\mathrm{LDH})$ released into the bathing medium $24 \mathrm{hr}$ after neurotoxic insults as described previously (Koh and Choi, 1987). The percentage of neuronal death was normalized to the mean $\mathrm{LDH}$ value released $24 \mathrm{hr}$ after continuous exposure to $500 \mu \mathrm{M}$ NMDA (equal to $100 \%$ ) or a sham control (equal to $0 \%$ ).

$\left[{ }^{3} \mathrm{H}\right] \quad(+)-5$-methyl-10,11-dihydro-5Hdibenzo $[a, d]$ cyclohepten-5,10-imine maleatebinding assays. The cerebral cortex was homogenized in $0.32 \mathrm{M}$ sucrose and centrifuged at $1000 \times g$ for $10 \mathrm{~min}$. The supernatant was subjected to centrifugation at $18,000 \times g$ for 20 min. The pellets were rehomogenized in icecold 5 mm Tris- $\mathrm{HCl}, \mathrm{pH} 7.7$, and recentrifuged at $8000 \times g$ for $20 \mathrm{~min}$. The resulting supernatant and top layer of pellets were combined and centrifuged at $40,000 \times g$ for $20 \mathrm{~min}$. The pellet was resuspended in $10 \mathrm{vol}$ of $5 \mathrm{~mm}$ Tris- $\mathrm{HCl}$, and the homogenate was centrifuged at

$40,000 \times g$ for $20 \mathrm{~min}$. This washing procedure was repeated twice. The final pellets were frozen at $-80^{\circ} \mathrm{C}$ overnight. The frozen pellets were thawed, resuspended in the $20 \mathrm{vol}$ of $5 \mathrm{~mm}$ Tris- $\mathrm{HCl}$, and centrifuged at $40,000 \times g$ for $20 \mathrm{~min}$ five times. The final pellet was suspended in HEPES-KOH buffer, $\mathrm{pH}$ 7.4. Protein concentration was adjusted to 400 $\mu \mathrm{g} / \mathrm{ml}$. Different concentrations of $\left[{ }^{3} \mathrm{H}\right]-(+)-5$-methyl-10,11-dihydro$5 \mathrm{H}$-dibenzo $[\mathrm{a}, \mathrm{d}]$ cyclohepten-5,10-imine maleate (MK-801), ranging from 0.1 to $40 \mathrm{~nm}$, were used as ligand. Synaptic membrane fractions (250 $\mu \mathrm{l}, 100 \mu \mathrm{g}$ protein equivalent) were incubated in a $500 \mu \mathrm{l}$ reaction mixture containing $20 \mathrm{~mm}$ HEPES-KOH, pH 7.4, at $23^{\circ} \mathrm{C}$ for $60 \mathrm{~min}$. Binding assays were started by adding different concentrations of $\left[{ }^{3} \mathrm{H}\right]-\mathrm{MK}-801$. The incubations were terminated by adding 5 vol of ice-cold HEPES$\mathrm{KOH}$ buffer and rapidly filtered though glass fiber filters (Type G-7; Inotech, Zurich, Switzerland) under negative pressure using a cell harvester (Inotech). The filters were washed twice with ice-cold buffer and dried overnight. Radioactivity retained in the filters was counted in $3 \mathrm{ml}$ of scintillation mixture (Ultima Gold; Packard, Groningen, Netherlands) in a liquid scintillation counter (Tri-Carb TR-2300; Packard). The nonspecific binding, which was always $<20 \%$, was determined by parallel binding assays using $10 \mu \mathrm{M}$ unlabelled MK-801. The kinetic constants ( $K_{\mathrm{d}}$ and $B_{\max }$ ) of the MK-801 binding were calculated by subjecting the data of the saturation isotherms to Scatchard analysis using commercially available software, GraphPad Prizm 3.0 (GraphPad Software, San Diego, CA). Protein concentration was determined on the basis of the method of Lowry et al. (1951).

Measurements of ${ }^{45} \mathrm{Ca}^{2+}$ influx. Cells were washed with a HEPESbuffered control salt solution (HCSS), added with ${ }^{45} \mathrm{Ca}^{2+}$ solutions (1 $\mu \mathrm{Ci} / \mathrm{ml}$ ) containing $300 \mu \mathrm{M}$ NMDA, and incubated for indicated points of time. Cells were washed with HCSS, lysed with $0.2 \%$ SDS, and subjected to measurement of ${ }^{45} \mathrm{Ca}^{2+}$ radioactivity.

Measurements of $\left[\mathrm{Ca}^{2+}\right]_{c}$ and $\left[\mathrm{Ca}^{2+}\right]_{m}$. Measurement of cytosolic-free calcium concentration $\left(\left[\mathrm{Ca}^{2+}\right]_{c}\right)$ was performed using a Ca ${ }^{2+}$-sensitive indicator fura-2 under a fluorescence microphotometry (Grynkiewicz et al., 1985). Forebrain cell cultures (DIV 11-14) grown on a glass-bottom dish were loaded with $5 \mu \mathrm{M}$ fura-2 AM plus $2 \%$ Pluronic F-127 for $30 \mathrm{~min}$ at $37^{\circ} \mathrm{C}$. We calculated actual $\left[\mathrm{Ca}^{2+}\right]_{c}$ in regions of interest in individual neurons with the formula: $\left[\mathrm{Ca}^{2+}\right]_{c}=K_{d} \cdot \beta\left(R-R_{\min }\right) /\left(R_{\max }-R\right)$, where $K_{d}$ is the dissociated constant of the indicator for $\mathrm{Ca}^{2+}, R$ is the ratio of fluorescence intensity at two different wavelengths $(340 / 380 \mathrm{~nm}$ for fura-2), and $R_{\min }$ and $R_{\max }$ are the ratios at zero $\mathrm{Ca}^{2+}$ and saturating $\mathrm{Ca}^{2+}$, respectively. Because accurate determination of F380-infinity, F380-zero, and $\beta$ were only possible in calibrations performed on sister dishes, we calculated actual $\left[\mathrm{Ca}^{2+}\right]_{c}$ in the experiment of NMDA- induced $\left[\mathrm{Ca}^{2+}\right]_{c}$ as a representation. In our condition, the ratio value of 1.0 is approximately equal to $700 \mathrm{~nm}$. Cells were washed three times with HCSS (120 mu NaCl, $5 \mathrm{~mm} \mathrm{KCl,} 2.3 \mathrm{~mm} \mathrm{CaCl}_{2}, 15 \mathrm{~mm}$ glucose, $20 \mathrm{~mm}$ HEPES, and $10 \mathrm{~mm} \mathrm{NaOH}, \mathrm{pH}$ 7.4). The fura-2 fluorescent signals $(\mathrm{Ex}=$ $340 / 380 \mathrm{~nm} ; \mathrm{Em}=510 \mathrm{~nm}$ ) were acquired with a Zeiss (Thornwood, NY) inverted microscope and CCD camera. Fura-2 ratio images were analyzed using an ion application (Empix Imaging, Ontario, Canada). To measure calcium concentration in the mitochondria $\left(\left[\mathrm{Ca}^{2+}\right]_{m}\right), 1 \mu \mathrm{M}$ rhod-2, a mitochondrial $\mathrm{Ca}^{2+}$-sensitive indicator, was loaded into forebrain cell cultures and then analyzed under a fluorescence microphotometry. Mitochondrial $\mathrm{Ca}^{2+}$ signal was evident by punctuated patterns of rhod-2 fluorescence and increased $\left[\mathrm{Ca}^{2+}\right]_{c}$ after administration of FCCP (carbonyl cyanide p-trifluoromethoxyphenyl-hydrazone), which induces mitochondrial $\mathrm{Ca}^{2+}$ release. The rhod-2 fluorescent signals $(E x=568 \mathrm{~nm} ; \mathrm{Em}=605 \mathrm{~nm})$ were acquired with a Nikon (Tokyo, Japan) Diaphot inverted microscope and CCD camera. Rhod-2 fluorescence images were collected at $5 \mathrm{sec}$ intervals and analyzed using a Quanticell 700 system (Applied Image, Rochester, NY). Changes in $\left[\mathrm{Ca}^{2+}\right]_{m}$ $\left(\Delta\left[\mathrm{Ca}^{2+}\right]_{m}\right)$ in forebrain neurons were estimated as $\Delta F / F 0$, where $\Delta F$ was defined as a drug-induced fluorescent intensity after subtracting the basal rhod-2 intensity ( $F 0$ ), and $F 0$ was derived from the average rhod-2 intensity in forebrain neurons from 10-20 frames (30 neurons per frame). Background was defined as nonspecific fluorescent signal in the cell-free region.

Measurement of mitochondrial membrane potential $\left(\Delta \psi_{m}\right)$. Forebrain neurons grown on a glass-bottom dish were treated with $1 \mu \mathrm{M}$ tetramethylrhodamine methyl ester (TMRM; a mitochondrial potential sensor) and incubated for $30 \mathrm{~min}$ at room temperature in the dark. To examine the TMRM fluorescent signal $(\mathrm{Ex}=549 \mathrm{~nm} ; \mathrm{Em}=573 \mathrm{~nm})$, cells were observed using confocal scanning laser microscopy (FV300; Oylmpus Optical, Tokyo, Japan) with an Olympus UPLAPO $40 \times$ objective ( 0.85 numerical aperture) and an additional digital magnification of $2 \times$. Images were obtained every $10 \mathrm{sec}$ after illuminating with a kryptonargon laser and then analyzed with FLUOVIEW software version 3.0.

\section{Results}

Induction of TERT mRNA in the adult brain after hypoxic-ischemic injury

Induction of TERT mRNA was observed in the cytoplasm of cortical neurons in peri-infarct regions within $4 \mathrm{hr}$ after permanent occlusion of MCAO (Fig. $1 A, B$ ). In these same peri-infarct areas, levels of TERT mRNA were further increased over $24 \mathrm{hr}$ after MCAO and then decreased thereafter (Fig. 1C). At $72 \mathrm{hr}$, the 

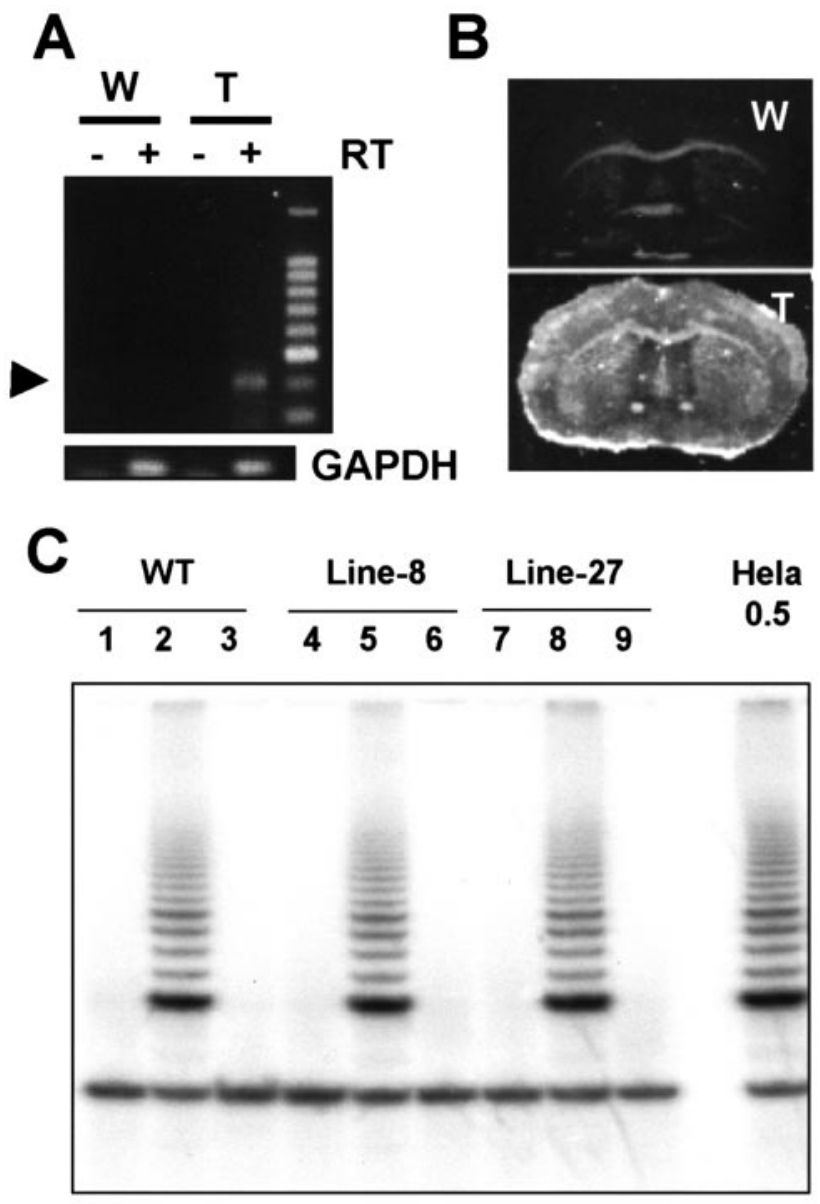

Figure 2. Generation of transgenic mice that overexpress mTERT ectopically. $A, B, R T-P C R$ $(A)$ and in situ hybridization histochemistry $(B)$ show overexpression of mTERT mRNA in the brain of transgenic mouse ( $\mathrm{T}$ ) compared with wild type (W). Reverse transcription reaction was performed using $1 \mu \mathrm{g}$ of brain total RNA in the presence $(+)$ or absence $(-)$ of reverse transcriptase. Amplification of GAPDH RNA was used as a normalizing control. C, Telomerase activity in the brain of transgenic mTERT-8, mTERT-27, and wild-type (WT) mice was not detected by radioactive TRAP assay using $0.5 \mu \mathrm{g}$ of lysate (lanes 1,4 , and 7 ). Heat-inactivated extract from the brain $(0.5 \mu \mathrm{g})$ was used as a negative control (lanes 3,6 , and 9 ). To rule out the possibility that the absence of telomerase activity results from RNase contamination or the presence of PCRinhibitors, the brain extract $(0.5 \mu \mathrm{g})$ was mixed with HeLa extract $(0.5 \mu \mathrm{g})$ and then the mixture was subjected to TRAP analysis (lanes 2, 5, and 8).

level was reduced to $\sim 20 \%$ of the peak. This result rendered us to investigate the protective role of TERT against several deathcausing stresses in the mouse brain.

Transgenic mice overexpressing mTERT is resistant against hypoxic-ischemic injury

To examine whether the induced expression of TERT plays a protective role against hypoxic-ischemia brain injury in vivo, we generated transgenic mice that overexpress TERT under the control of the chicken $\beta$-actin promoter. Ectopic expression of mTERT mRNA was identified by both RT-PCR and in situ hybridization in the brain of transgenic mice (Fig. 2, $A$ and $B$, respectively). Most of the experiments were performed with transgenic line mTERT-27 and, to verify the result of mTERT-27, another founder line (mTERT-8) was also used. However, even though TERT mRNA was expressed, we could not detect telomerase activity in conventional radioactive TRAP assay (Fig. 2C). TERC, the RNA component of telomerase that serves as a template for telomere synthesis and is essential for telomerase activ-
A

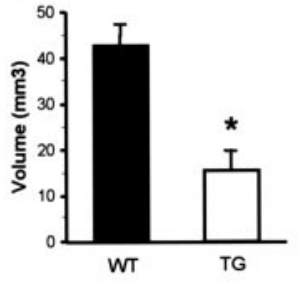

B

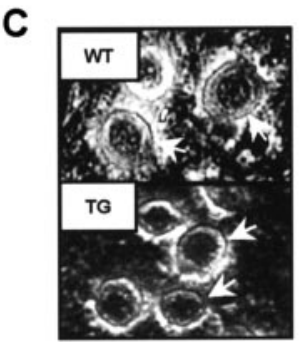

D
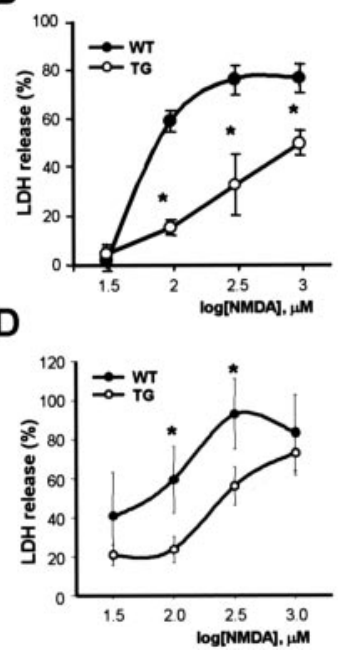

Figure 3. Neuroprotective effects of mTERT against hypoxic-ischemic brain injury and NMDA receptor-mediated excitotoxicity. $A$, Permanent cerebral ischemia by occlusion of middle cerebral artery was performed in mTERT transgenic mice (TG) and wild-type mice (WT). The volume of the infarction was analyzed $24 \mathrm{hr}$ later after staining with TTC (mean \pm SEM; $n=15$ and 8 for WT and TG, respectively). ${ }^{*}$, Significant difference between WT and TG ( $p<0.05$ using the independent $t$ test). $B$, Forebrain cell cultures (DIV 11-14) derived from TG and WT were exposed to various doses of NMDA for $10 \mathrm{~min}$. Neuronal death was analyzed $24 \mathrm{hr}$ later by measuring LDH efflux into bathing medium (mean $\pm \mathrm{SEM} ; n=8$ culture wells per condition). *, Significant difference from relevant control (WT) at $p<0.05$ using ANOVA and StudentNeuman-Keuls test. C, Phase contrast photomicrographs of forebrain cell cultures from WT and TG taken $10 \mathrm{~min}$ after exposure to $300 \mu \mathrm{m}$ NMDA for $10 \mathrm{~min}$. Note that swelling of neuronal cell body from WT (arrow) was not observed in forebrain neurons from TG. D, TERT protects NMDAinduced neurotoxicity in differentiated P19 cells. P19 embryonic carcinoma cells that stably express TERT were established and then differentiated to neuron-like cells by treating with retinoic acid. Differentiated cells were briefly (10 min) exposed to NMDA (30-1000 $\mu \mathrm{M})$, and cell death was assessed by measuring LDH release $24 \mathrm{hr}$ later (mean \pm SEM; $n=4$ culture wells per condition). * Significant difference from relevant control (WT) at $p<0.05$ using ANOVA and Student-Neuman-Keuls test.

ity, is undetectable in the brain tissue of mice and rats by conventional RT-PCR or Northern blot technique (Blasco et al., 1995; Artandi et al., 2002; Holzmann et al., 2003). This suggests the possibility that lack of telomerase activity in transgenic brain tissue results from the absence of TERC component, and therefore TERT expression may not be sufficient for reconstitution of telomerase enzyme activity in brain tissue. Detailed histological analysis of the mTERT transgenic mice did not reveal any anatomical or cytoarchitectural abnormalities.

We performed experiments to investigate whether ectopic mTERT expression would modulate ischemic brain damage after MCAO (Shigeno et al., 1985). In wild-type mice, MCAO produced a cerebral infarct of $\sim 42.7 \mathrm{~mm}^{3}( \pm 4.7)$ after $24 \mathrm{hr}$. However, the volume of the cerebral infarct was significantly smaller in mTERT transgenic mice $\left(15.4 \mathrm{~mm}^{3}, \pm 4.2\right.$; mTERT-27; $p<$ 0.05 ) (Fig. 3A). Similar results were also obtained from another transgenic line (mTERT-8; data not shown).

\section{Overexpression of mTERT shows protective effect against NMDA toxicity}

Excitotoxicity, oxidative stress, and apoptosis comprise the major routes to neuronal death evolving after focal cerebral and global forebrain ischemia (Gwag et al., 2002). Thus, we examined whether TERT overexpression would protect against hypoxicischemic brain injury through modulation of excitotoxicity, oxidative stress, and apoptosis. 
We investigated the putative effects of TERT overexpression against excitotoxicity in forebrain cell cultures. Excess activation of ionotropic glutamate receptors sensitive to NMDA, AMPA, or kainate causes fulminant neuronal cell necrosis resulting from massive influx of $\mathrm{Ca}^{2+}$ and $\mathrm{Na}^{+}$. A brief exposure to $100-300 \mu \mathrm{M}$ NMDA produced $60-80 \%$ neuronal death in forebrain cell cultures that were obtained from wild-type mice (Fig. 3B). NMDA-induced neuronal death was markedly reduced to $15-30 \%$ in cultures from mTERT transgenic mice (Fig. 3C). Neuroprotective action of telomerase against NMDA neurotoxicity was further validated in neurons differentiated from P19 embryonic carcinoma cells that express NMDA receptors and stably overexpress mTERT (Fig. 3D). In contrast to reduced sensitivity to NMDA neurotoxicity, forebrain cultures from transgenic and wild-type mice showed the similar levels of neuronal death $24 \mathrm{hr}$ after continuous exposure to 20-60 $\mu \mathrm{M}$ kainate (Fig. $4 A$ ). This implies that overexpression of mTERT protects forebrain neurons from excitotoxicity selectively by preventing rapidly evolving NMDA neurotoxicity.

Because anti-oxidant effects of telomerase have been reported in fibroblast cells transfected with human TERT (Ren et al., 2001), mTERT may protect against hypoxic-ischemic brain injury by reducing ROS (reactive oxygen species)-mediated neuronal death. Administration of 0.3-100 $\mu \mathrm{M} \mathrm{Fe}^{2+}$, a free radical-inducing transition metal through Fenton chemistry, produced dose-dependent neuronal cell necrosis in forebrain cell cultures $24 \mathrm{hr}$ later (Fig. 4 B). $\mathrm{Fe}^{2+}$. induced oxidative neuronal cell death was not attenuated in cultures from mTERT transgenic mice. This suggests that mTERT likely attenuates hypoxic-ischemic neuronal cell death irrespective of oxidative stress.

Several lines of evidence suggest that dysfunction of telomere and telomerase can induce apoptosis in some cell types (Hemann et al., 2001; Boklan et al., 2002; Cao et al., 2002b). Thus, we tested whether overexpression of mTERT could contribute to the protection from apoptosis in the postmitotic neurons. Neuron-rich forebrain cell cultures from wild-type mice revealed widespread neuronal cell apoptosis $24 \mathrm{hr}$ after serum deprivation, which was accompanied by shrinkage of cell body as reported previously (Koh et al., 1995). Forebrain neurons from mTERT transgenic mice underwent similar levels of apoptosis after serum deprivation (Fig. 4C). Together, enforced expression of TERT renders neurons highly resistant to NMDA receptor-mediated excitotoxicity without influencing non-NMDA receptor-mediated excitotoxicity, oxidative stress, and apoptosis.

\section{Overexpression of mTERT prevents $\left[\mathrm{Ca}^{2+}\right]_{c}$ accumulation after NMDA receptor activation}

Influx and accumulation of $\mathrm{Ca}^{2+}$ are required for NMDA receptor-mediated neuronal cell death (Choi, 1985). We observed that administration of NMDA induced a gradual increase
B

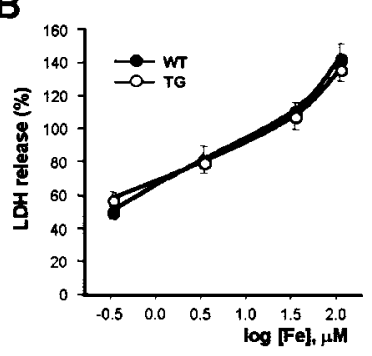

C

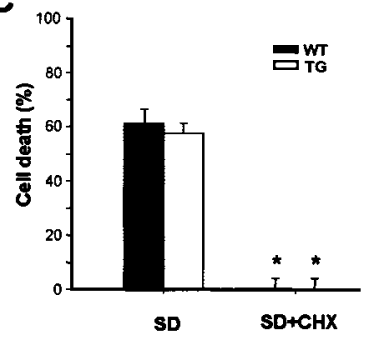

Figure 4. Effects of TERT on non-NMDA-induced excitotoxicity, oxidative stress, and apoptosis. $A, B$, Forebrain cell cultures (DIV 11-14) derived from mTERT transgenic mice (TG) and their wild-type littermates (WT) were continuously exposed to 20-60 $\mu \mathrm{M}$ kainate $(A)$ or $0.3-100 \mu \mathrm{m} \mathrm{Fe}^{2+}(B)$. Neuronal cell death was analyzed $24 \mathrm{hr}$ later by measuring $\mathrm{LDH}$ efflux into bathing medium (mean prevent serum deprivation-induced neuronal apoptosis sensitive to cycloheximide, a protein synthesis inhibitor known to block

2. Reduction in NMDA-induced accumulation of intracellular free calcium in forebrain neurons from mTERT transgenic C
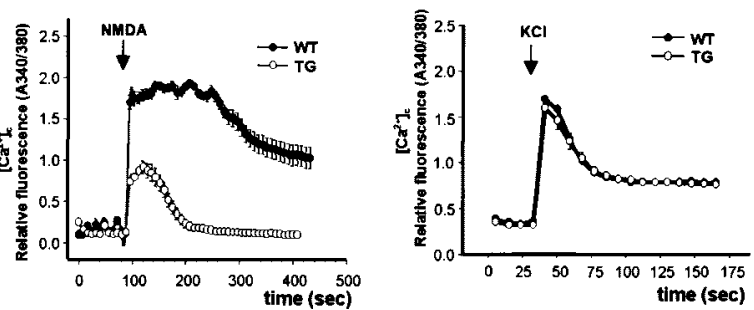

me (sec) mice. $A$, Forebrain cell cultures from WT and TG were exposed to a sham wash (sham) or $100 \mu \mathrm{m}$ NMDA for indicated points of time. $\mathrm{Ca}^{2+}$ influx was analyzed by measuring influx of ${ }^{45} \mathrm{Ca}^{2+}$ into cultured cells. B, C, Forebrain cell cultures from WT and TG were

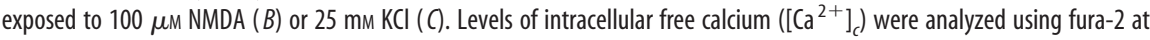

in ${ }^{45} \mathrm{Ca}^{2+}$ influx in forebrain cell cultures from wild-type mice. NMDA-induced $\mathrm{Ca}^{2+}$ influx was not altered in cultures from mTERT transgenic mice (Fig. 5A). Binding experiments of $\left[{ }^{3} \mathrm{H}\right] \mathrm{MK}-801$ were performed to examine whether or not the NMDA receptor function would be affected by the TERT overexpression. Nonlinear curve-fitting analysis demonstrated that specific $\left[{ }^{3} \mathrm{H}\right] \mathrm{MK}-801$ binding to mice cortical membranes was consistent with a single-site model. A comparison of the $K_{\mathrm{d}}$ and $B_{\max }$ values between TERT transgenic and wild-type mice showed no significant difference (Table 1). Thus, TERT appears to prevent NMDA neurotoxicity by modulating downstream signaling pathways of the NMDA receptors.

We then tested, by $\mathrm{Ca}^{2+}$ imaging, whether TERT would prevent accumulation of cytosolic free calcium $\left(\left[\mathrm{Ca}^{2+}\right]_{c}\right)$ after activation of NMDA receptors. Administration of NMDA immediately produced a large and long-lasting increase in $\left[\mathrm{Ca}^{2+}\right]_{c}$ in wild-type forebrain neurons (Fig. 5B). The NMDA-induced increase in $\left[\mathrm{Ca}^{2+}\right]_{c}$ was much smaller in the neurons from transgenic mice, which returned rapidly to the basal level. Additional experiments were performed to determine whether TERT would reduce depolarization-induced $\left[\mathrm{Ca}^{2+}\right]_{c}$ rise as well as NMDAinduced $\left[\mathrm{Ca}^{2+}\right]_{c}$ rise. High $\mathrm{K}^{+}$-induced $\left[\mathrm{Ca}^{2+}\right]_{c}$ rise in the presence of an NMDA receptor antagonist MK-801 was not reduced in forebrain neurons from mTERT transgenic mice (Fig. $5 C$ ). Together, TERT specifically attenuates NMDA neurotoxicity by reducing $\left[\mathrm{Ca}^{2+}\right]_{c}$ rise after activation of NMDA receptors. 
Table 1. The binding capacity $\left(B_{\max }\right)$ and the affinity of $\left[{ }^{3} \mathrm{H}\right] \mathrm{MK}-801$ for synaptosomal membranes of TERT transgenic and wild-type mice

\begin{tabular}{lll}
\hline Mice & $B_{\max }(\mathrm{pmol} / \mathrm{mg}$ of protein) & $K_{\mathrm{d}}(\mathrm{nm})$ \\
\hline Wild type & $3.86 \pm 0.36$ & $2.07 \pm 0.19$ \\
TERT transgenic & $3.52 \pm 0.41^{*}$ & $1.73 \pm 0.15^{*}$ \\
\hline
\end{tabular}

Each value represents mean \pm SEM ( $n=4$ for each condition). $K_{\mathrm{d}}$ and $B_{\max }$ values were calculated by subjecting the saturation isotherms data to Scatchard analysis and analyzed between wild-type and TERT transgenic mice using Student's $t$ test. ${ }^{*}$, Not significant.

\section{Overexpression of mTERT enhances the basal level of} mitochondrial membrane potential and uptake of cytosolic $\mathrm{Ca}^{2+}$ into mitochondria after administration of NMDA

Because NMDA-induced $\mathrm{Ca}^{2+}$ influx was not different between mTERT transgenic and wild-type mice, we investigated whether mitochondria, an intracellular $\mathrm{Ca}^{2+}$ store, would be involved in reduced $\left[\mathrm{Ca}^{2+}\right]_{c}$ accumulation after exposure of NMDA to forebrain neurons from mTERT transgenic mice. To evaluate mitochondrial $\mathrm{Ca}^{2+}$ concentration $\left(\left[\mathrm{Ca}^{2+}\right]_{m}\right)$, we used rhod-2, the selective mitochondrial $\mathrm{Ca}^{2+}$ indicator as well as the protonophore FCCP, which abolishes $\left[\mathrm{Ca}^{2+}\right]_{m}$ rise by collapsing electrochemical proton gradient and thus $\Delta \psi_{m}$. Thus, assessing $\left[\mathrm{Ca}^{2+}\right]_{c}$ during an FCCP application in the absence of extracellular $\mathrm{Ca}^{2+}$ corresponds to measuring $\left[\mathrm{Ca}^{2+}\right]_{m}$ (Brocard et al., 2001). The fluorescent signal of rhod-2 in neurons was increased immediately after exposure of forebrain cell cultures to $100 \mu \mathrm{M}$ NMDA in wild-type mice. NMDA-induced rhod-2 signal was markedly increased in forebrain neurons from mTERT transgenic mice compared with the wild type (Fig. $6 A$ ). Enhanced increase in $\left[\mathrm{Ca}^{2+}\right]_{m}$ in mTERT transgenic mice was confirmed by gradual increase in $\left[\mathrm{Ca}^{2+}\right]_{c}$ after the addition of FCCP subsequent to administration of NMDA (Fig. $6 \mathrm{~B}$ ). Concurrent addition of FCCP fully reversed the reduced $\left[\mathrm{Ca}^{2+}\right]_{c}$ in mTERT transgenic mice after NMDA treatment (Fig. 6C). Concurrent treatment with FCCP or Ruthenium red, an inhibitor of mitochondrial $\mathrm{Ca}^{2+}$ uniporter, reversed the neuroprotective effects of mTERT (Fig. 6D). This implies that enhanced uptake of $\mathrm{Ca}^{2+}$ into mitochondria is required for the effects of mTERT preventing accumulation of $\left[\mathrm{Ca}^{2+}\right]_{c}$ and neuronal death after administration of NMDA.

Activation of NMDA receptors causes overloading of mitochondrial $\mathrm{Ca}^{2+}$ and loss of $\Delta \psi_{m}$, which results in interrupted ATP synthesis and eventual neuronal cell death (Nicholls and Budd, 1998). We observed that $\Delta \psi_{m}$ was markedly increased in neurons from TERT transgenic mice (Fig. $6 E, F) . \Delta \psi_{m}$ in cultured neurons from TERT transgenic mice was also reduced after administration of NMDA but still remained elevated compared with control neurons from wild-type mice.

\section{Discussion}

We provide the first in vivo evidence that expression of TERT mRNA is induced in postmitotic neurons after cerebral ischemia in adult mice. Transgenic mice overexpressing TERT are resistant against ischemic cerebral injury by permanent occlusion of the middle cerebral artery. The protective effects of TERT are attributable to selective prevention of NMDA receptor-mediated excitotoxicity through reducing accumulation of $\left[\mathrm{Ca}^{2+}\right]_{c}$ and enhancing $\mathrm{Ca}^{2+}$ uptake into mitochondria.

In the nervous system, expression of TERT is detectable in brain cells during development (Fu et al., 2000) and even in adult brain tissue (Martin-Rivera et al., 1998). Also, TERT could be induced in microglial cells after administration of kainate in adult mice (Fu et al., 2002). In the present study, fluorescence in situ hybridization histochemistry showed that the catalytic subunit of mTERT was not detectable normally in adult mouse brain. Inter- estingly, the level of mTERT mRNA was markedly increased in cortical neurons in the territory of middle cerebral artery within 4 $\mathrm{hr}$ after permanent occlusion of MCAO in adult mice. Because expression of c-Myc, a direct regulator of TERT expression ( $\mathrm{Wu}$ et al., 1999), is rapidly induced in cortical neurons after focal cerebral ischemia in adult rat (Nakagomi et al., 1996), it is possible that c-Myc may contribute to expression of TERT in mature neurons subjected to ischemic injury. Although additional study is needed to understand mechanisms underlying induction of TERT in postmitotic neurons, the induced expression of TERT suggests that TERT plays a role in the process of neuronal death after hypoxic-ischemic brain injury besides cell proliferation and senescence. In support of this, mTERT transgenic mice did not show changes in physiological variables such as arterial blood pressure, rectal temperature, blood $\mathrm{pH}$, and $\mathrm{PaO}_{2} / \mathrm{PaCO}_{2}$ (data not shown) but resulted in significantly reduced infarct volume after MCAO. This raises an intriguing possibility that TERT exerts its protective effects by directly preventing neuronal death after focal cerebral ischemia.

Excitotoxicity, oxidative stress, and apoptosis comprise the major routes to neuronal death after hypoxic-ischemic brain injury. Transgenic expression of mTERT renders neurons highly resistant to NMDA receptor-mediated excitotoxic neuronal cell necrosis without influencing necrosis by non-NMDA receptormediated excitotoxicity and oxidative stress. Moreover, TERT overexpression did not protect neurons from apoptosis. The novel neuroprotective action of TERT against NMDA neurotoxicity seems to be independent of intrinsic telomerase enzyme activity as evident by lack of telomerase activity in mTERT transgenic brain tissue. This was supported by an additional experiment showing that pretreatment with $3^{\prime}$-azido-2' $3^{\prime}$ dideoxythymidine, an inhibitor of telomerase, did not reverse the protective effects of TERT against NMDA. The protective effects of TERT have been reported in other types of cells regardless of telomerase activity (Cao et al., 2002a). These observations suggest that the function of telomerase to elongate and maintain telomeres may not be required for the protective effects of TERT against hypoxic-ischemic injury and NMDA neurotoxicity. Enforced expression of TERT likely prevents NMDA neurotoxicity through a novel mechanism that presumably interferes with NMDA receptors or their downstream signals in primary neurons, independent of enzyme activity and telomere lengthening, although the precise mechanisms remain elusive.

Influx and accumulation of $\mathrm{Ca}^{2+}$ are required for NMDA receptor-mediated neuronal cell death (Choi, 1985). In cultured forebrain neurons, NMDA-induced $\mathrm{Ca}^{2+}$ influx was not different between mTERT transgenic and wild-type mice, suggesting that mTERT prevents NMDA neurotoxicity without changing NMDA-induced $\mathrm{Ca}^{2+}$ influx. NMDA-induced $\left[\mathrm{Ca}^{2+}\right]_{c}$ accumulation was rapidly reduced in forebrain neurons from mTERT transgenic mice. The buffering effect of mTERT was specific to $\left[\mathrm{Ca}^{2+}\right]_{c}$ rise after activation of NMDA receptors as neuronal $\left[\mathrm{Ca}^{2+}\right]_{c}$ accumulation after depolarization was similar in forebrain cell cultures from transgenic and wild-type mice. Thus, the neuroprotective effect of TERT was attributable to prevention of NMDA-induced $\left[\mathrm{Ca}^{2+}\right]_{c}$ accumulation.

${ }^{45} \mathrm{Ca}^{2+}$ influx after administration of NMDA was not altered in cultures from mTERT transgenic mice, excluding the possibility that neurons expressing mTERT would extrude accumulated $\left[\mathrm{Ca}^{2+}\right]_{c}$ more than wild-type neurons. Accumulated $\left[\mathrm{Ca}^{2+}\right]_{c} \mathrm{can}$ be sequestered into the endoplasmic reticulum through ATPdependent uptake or the mitochondria matrix through passive entry. In contrast to the endoplasmic reticulum with high- 
affinity $\mathrm{Ca}^{2+}$ binding sites that buffer transient accumulation in $\left[\mathrm{Ca}^{2+}\right]_{c}$, the mitochondria can reduce sustained $\mathrm{Ca}^{2+}$ overload in the cytosol by taking up $\mathrm{Ca}^{2+}$ through a $\mathrm{Ca}^{2+}$ uniporter (Rizzuto et al., 2000). Thus, it is conceivable to reason that the mitochondria contribute to buffering NMDA-induced $\left[\mathrm{Ca}^{2+}\right]_{c}$ overload in forebrain neurons from mTERT transgenic mice. In support of this, analysis of $\left[\mathrm{Ca}^{2+}\right]_{m}$ using the fluorescent $\mathrm{Ca}^{2+}$ dye rhod-2 revealed that $\mathrm{Ca}^{2+}$ accumulated in the cytosol after administration of NMDA was rapidly and substantially sequestered into the mitochondria in neurons from the transgenic mice compared with the wild type. The mitochondrial uptake of cytosolic $\mathrm{Ca}^{2+}$ in the transgenic mice was further supported by release of accumulated mitochondrial $\mathrm{Ca}^{2+}$ into the cytosol by blockade of mitochondrial $\mathrm{Ca}^{2+}$ uptake with FCCP. $\left[\mathrm{Ca}^{2+}\right]_{m}$ overload was shown to mediate NMDA receptor-mediated glutamate neurotoxicity in part as shown by reduced glutamate neurotoxicity in the presence of maneuvers preventing mitochondrial $\mathrm{Ca}^{2+}$ uptake (Stout et al., 1998). Interestingly, FCCP, a selective blocker of mitochondrial $\mathrm{Ca}^{2+}$ uptake, completely reversed effects of mTERT, reducing NMDA-induced neuronal death. Ruthenium red, a relatively specific inhibitor of mitochondrial calcium uniporter, also reversed the neuroprotective effects of mTERT against NMDA. This implies that enhanced mitochondrial $\mathrm{Ca}^{2+}$ accumulation was required for the neuroprotective effects of mTERT against NMDA injury.

$\left[\mathrm{Ca}^{2+}\right]_{m}$ overload can mediate NMDA neurotoxicity in part through interrupting $\Delta \psi_{m}$ and ATP synthesis (Nicholls and Budd, 1998; Stout et al., 1998; Nicholls and Ward, 2000). We observed that accumulation of TMRM was considerably high in neurons from TERT transgenic mice compared with wild-type mice under normal conditions. Accumulation of TMRM likely represents an increase in $\Delta \psi_{m}$ but may be attributable to a difference in plasma membrane potential. However, the latter is improbable in view of other results showing that $\left[\mathrm{Ca}^{2+}\right]_{i}$ transients are not altered in neurons from TERT transgenic mice after exposure to a depolarization stimulus by high $\mathrm{K}^{+} . \Delta \psi_{m}$ in neurons from TERT transgenic mice was also reduced after administration of NMDA but still remained elevated compared with control levels from wild-type mice. This renders neurons from TERT transgenic mice highly resistant against NMDA neurotoxicity and possibly hypoxic-ischemic injury. Along this line, Bcl-2expressing cells show increase in mitochondrial $\mathrm{Ca}^{2+}$ uptake and resistance to $\mathrm{Ca}^{2+}$-induced respiratory injury (Martinou et al., 1994; Murphy et al., 1996). Prolonged treatment with high glucose was shown to protect cultured cortical neurons against NMDA and deprivation of oxygen and glucose through enhanced $\Delta \psi_{m}$ (Seo et al., 1999).

Besides the central role of TERT in bypassing cellular senescence in actively dividing mitotic cells, TERT appears to play a dynamic role in modulation of neuronal survival in developing NMDA for $300 \mathrm{sec}$.
B

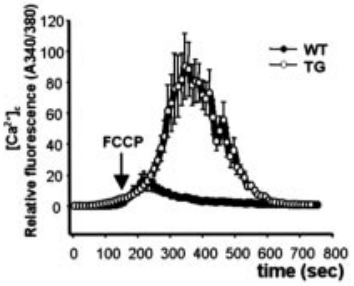

C

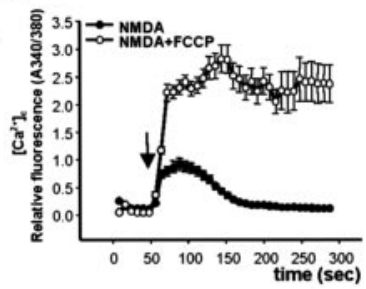

$\mathbf{E}$

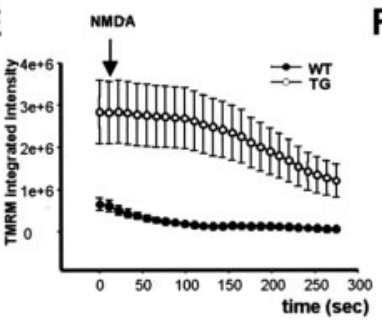

$\mathbf{F}$

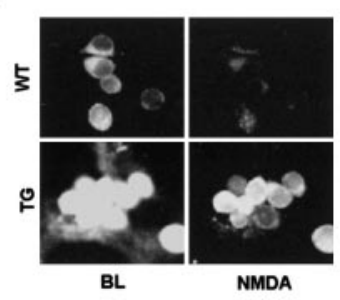

Figure 6. Enhanced mitochondrial $\mathrm{Ca}^{2+}$ capacity in mTERT transgenic mice is required for protective effects against NMDA. A, The rhod-2 fluorescence change elicited by $100 \mu \mathrm{M}$ NMDA in forebrain cell cultures (DIV 11-14) from WT and TG. Levels of mitochondrial calcium $\left(\left[\mathrm{Ca}^{2+}\right]_{m}\right.$ ) were analyzed using rhod-2 (mean $\pm \mathrm{SEM} ; n=20-30$ randomly chosen neurons from 3 dishes per condition). $B$, Release of NMDA-induced mitochondrial $\mathrm{Ca}^{2+}$ into the cytosol. Forebrain cell cultures from WT and TG 政 chosen neurons from 3 dishes per condition). F, Fluorescence photomicrograph of TMRM showing mitochondrial membrane potential in cultured forebrain neurons from WT and TG before (left panel, BL) or after (right panel, NMDA) exposure to $100 \mu \mathrm{M}$

and postmitotic mature nervous system. In particular, TERT is inducible in the adult brain and can protect neurons from ischemic brain injury by preventing NMDA receptor-mediated excitotoxic necrosis. The novel neuroprotective actions of TERT involve enhanced $\Delta \psi_{m}$ and may be applied to treat hypoxicischemia brain injury and other age-related neurological diseases in which NMDA receptor excitotoxicity has been implicated.

\section{References}

Artandi SE, Alson S, Tietze MK, Sharpless NE, Ye S, Greenberg RA, Castrillon DH, Horner JW, Weiler SR, Carrasco RD, DePinho RA (2002) Constitutive telomerase expression promotes mammary carcinomas in aging mice. Proc Natl Acad Sci USA 99:8191-8196.

Bederson JB, Pitts LH, Germano SM, Nishimura MC, Davis RL, Bartkowski HM (1986) Evaluation of 2,3,5-triphenyltetrazolium chloride as a stain for detection and quantification of experimental cerebral infarction in rats. Stroke 17:1304-1308.

Blasco MA, Funk W, Villeponteau B, Greider CW (1995) Functional characterization and developmental regulation of mouse telomerase RNA. Science 269:1267-1270.

Bodnar AG, Ouellette M, Frolkis M, Holt SE, Chiu CP, Morin GB, Harley CB, Shay JW, Lichtsteiner S, Wright WE (1998) Extension of life-span by introduction of telomerase into normal human cells. Science 279:349-352.

Boklan J, Nanjangud G, MacKenzie KL, May C, Sadelain M, Moore MA (2002) Limited proliferation and telomere dysfunction following telomerase inhibition in immortal murine fibroblasts. Cancer Res 62:2104-2114.

Boutou E, Hurel C, Matsas R (2000) Early expression of the BM88 antigen during neuronal differentiation of P19 embryonal carcinoma cells. Int J Dev Neurosci 18:321-328. 
Brocard JB, Tassetto M, Reynolds IJ (2001) Quantitative evaluation of mitochondrial calcium content in rat cortical neurons following a glutamate stimulus. J Physiol (Lond) 531:793-805.

Burger AM, Bibby MC, Double JA (1997) Telomerase activity in normal and malignant mammalian tissues: feasibility of telomerase as a target for cancer chemotherapy. Br J Cancer 75:516-522.

Cao Y, Li H, Deb S, Liu JP (2002a) TERT regulates cell survival independent of telomerase enzymatic activity. Oncogene 21:3130-3138.

Cao Y, Li H, Mu FT, Ebisui O, Funder JW, Liu JP (2002b) Telomerase activation causes vascular smooth muscle cell proliferation in genetic hypertension. FASEB J 16:96-98.

Choi DW (1985) Glutamate neurotoxicity in cortical cell culture is calcium dependent. Neurosci Lett 58:293-297.

Fu W, Killen M, Culmsee C, Dhar S, Pandita TK, Mattson MP (2000) The catalytic subunit of telomerase is expressed in developing brain neurons and serves a cell survival-promoting function. J Mol Neurosci 14:3-15.

Fu W, Lee J, Guo Z, Mattson MP (2002) Seizures and tissue injury induce telomerase in hippocampal microglial cells. Exp Neurol 178:294-300.

Greenberg RA, Allsopp RC, Chin L, Morin GB, DePinho RA (1998) Expression of mouse telomerase reverse transcriptase during development, differentiation and proliferation. Oncogene 16:1723-1730.

Grynkiewicz G, Poenie M, Tsien RY (1985) A new generation of Ca2+ indicators with greatly improved fluorescence properties. J Biol Chem 260:3440-3450.

Gwag BJ, Won SJ, Kim DY (2002) Excitotoxicity, oxidative stress and apoptosis in ischemic neuronal death. In: New concepts in cerebral ischemia (Lin RCS, ed), pp 79-112. Boca Raton, FL: CRC.

Harley CB, Futcher AB, Greider CW (1990) Telomeres shorten during ageing of human fibroblasts. Nature 345:458-460.

Hemann MT, Rudolph KL, Strong MA, Depinho RA, Chin L, Greider CW (2001) Telomere dysfunction triggers developmentally regulated germ cell apoptosis. Mol Biol Cell 12:2023-2030.

Holzmann K, Berger W, Mejri D, Cerni C, Sasgary S (2003) Detection and quantification of transcripts for the catalytic subunit TERT and the RNA component of telomerase in rat tissue. Anal Biochem 317:120-123.

Kim NW, Piatyszek MA, Prowse KR, Harley CB, West MD, Ho PL, Coviello GM, Wright WE, Weinrich SL, Shay JW (1994) Specific association of human telomerase activity with immortal cells and cancer. Science 266:2011-2015.

Koh JY, Choi DW (1987) Quantitative determination of glutamate mediated cortical neuronal injury in cell culture by lactate dehydrogenase efflux assay. J Neurosci Methods 20:83-90.

Koh JY, Gwag BJ, Lobner D, Choi DW (1995) Potentiated necrosis of cultured cortical neurons by neurotrophins. Science 268:573-575.

Lowry OH, Rosebrough NJ, Farr AL, Randall RJ (1951) Protein measurement with folin-phenol reagent. J Biol Chem 193:265-275.

Martin-Rivera L, Herrera E, Albar JP, Blasco MA (1998) Expression of mouse telomerase catalytic subunit in embryos and adult tissues. Proc Natl Acad Sci USA 95:10471-10476.

Martinou JC, Dubois-Dauphin M, Staple JK, Rodriguez I, Frankowski H, Missotten M, Albertini P, Talabot D, Catsicas S, Pietra C (1994) Overexpression of BCL-2 in transgenic mice protects neurons from naturally occurring cell death and experimental ischemia. Neuron 13:1017-1030.

Meyerson M, Counter CM, Eaton EN, Ellisen LW, Steiner P, Caddle SD, Ziaugra L, Beijersbergen RL, Davidoff MJ, Liu Q, Bacchetti S, Haber DA, Weinberg RA (1997) hEST2, the putative human telomerase catalytic subunit gene, is up-regulated in tumor cells and during immortalization. Cell 90:785-795.
Minamino T, Mitsialis SA, Kourembanas S (2001) Hypoxia extends the life span of vascular smooth muscle cells through telomerase activation. Mol Cell Biol 21:3336-3342.

Murphy AN, Bredesen DE, Cortopassi G, Wang E, Fiskum G (1996) Bcl-2 potentiates the maximal calcium uptake capacity of neural cell mitochondria. Proc Natl Acad Sci USA 93:9893-9898.

Nakagomi T, Asai A, Kanemitsu H, Narita K, Kuchino Y, Tamura A, Kirino T (1996) Up-regulation of c-myc gene expression following focal ischemia in the rat brain. Neurol Res 18:559-563.

Nakamura TM, Morin GB, Chapman KB, Weinrich SL, Andrews WH, Lingner J, Harley CB, Cech TR (1997) Telomerase catalytic subunit homologs from fission yeast and human. Science 277:955-959.

Nicholls DG, Budd SL (1998) Neuronal excitotoxicity: the role of mitochondria. Biofactors 8:287-299.

Nicholls DG, Ward MW (2000) Mitochondrial membrane potential and neuronal glutamate excitotoxicity: mortality and millivolts. Trends Neurosci 23:166-174.

Niwa H, Yamamura K, Miyazaki J (1991) Efficient selection for high-expression transfectants with a novel eukaryotic vector. Gene 108:193-199.

Noh JS, Gwag BJ (1997) Attenuation of oxidative neuronal necrosis by a dopamine D1 agonist in mouse cortical cell cultures. Exp Neurol 146:604-608.

Nugent CI, Lundblad V (1998) The telomerase reverse transcriptase: components and regulation. Genes Dev 12:1073-1085.

Oh H, Taffet GE, Youker KA, Entman ML, Overbeek PA, Michael LH, Schneider MD (2001) Telomerase reverse transcriptase promotes cardiac muscle cell proliferation, hypertrophy, and survival. Proc Natl Acad Sci USA 98:10308-10313.

Ren JG, Xia HL, Tian YM, Just T, Cai GP, Dai YR (2001) Expression of telomerase inhibits hydroxyl radical-induced apoptosis in normal telomerase negative human lung fibroblasts. FEBS Lett 488:133-138.

Rizzuto R, Bernardi P, Pozzan T (2000) Mitochondria as all-round players of the calcium game. J Physiol (Lond) 529:37-47.

Seimiya H, Tanji M, Oh-hara T, Tomida A, Naasani I, Tsuruo T (1999) Hypoxia up-regulates telomerase activity via mitogen-activated protein kinase signaling in human solid tumor cells. Biochem Biophys Res Commun 260:365-370.

Seo SY, Kim EY, Kim H, Gwag BJ (1999) Neuroprotective effect of high glucose against NMDA, free radical, and oxygen-glucose deprivation through enhanced mitochondrial potentials. J Neurosci 19:8849-8855.

Shay JW, Bacchetti S (1997) A survey of telomerase activity in human cancer. Eur J Cancer 33:787-791.

Shigeno T, McCulloch J, Graham DI, Mendelow AD, Teasdale GM (1985) Pure cortical ischemia versus striatal ischemia. Circulatory, metabolic, and neuropathologic consequences. Surg Neurol 24:47-51.

Stout AK, Raphael HM, Kanterewicz BI, Klann E, Reynolds IJ (1998) Glutamate-induced neuron death requires mitochondrial calcium uptake. Nat Neurosci 1:366-373.

Wright WE, Piatyszek MA, Rainey WE, Byrd W, Shay JW (1996) Telomerase activity in human germline and embryonic tissues and cells. Dev Genet 18:173-179.

Wu KJ, Grandori C, Amacker M, Simon-Vermot N, Polack A, Lingner J, Dalla-Favera R (1999) Direct activation of TERT transcription by c-MYC. Nat Genet 21:220-224.

Zhu H, Fu W, Mattson MP (2000) The catalytic subunit of telomerase protects neurons against amyloid beta-peptide-induced apoptosis. J Neurochem 75:117-124. 